\title{
Art and Design Education in the Times of the Coronavirus (Covid-19) Pandemic in Turkey
}

\author{
Evrim Caglayan ${ }^{1}$ \\ ${ }^{1}$ Fethi Toker Faculty of Fine Arts and Design, Karabuk University, Karabuk, Turkey \\ Correspondence: Evrim Caglayan, Fethi Toker Faculty of Fine Arts and Design, Karabuk University, Safranbolu, \\ Karabuk, Turkey.
}

Received: April 23, 2021

Accepted: July 12, 2021

Online Published: October 27, 2021

doi:10.5539/ies.v14n11p43

URL: https://doi.org/10.5539/ies.v14n11p43

\begin{abstract}
The Coronavirus (Covid-19) pandemic, which started in the People's Republic of China in December 2019, spread to the entire world at the beginning of 2020 and affected all areas of social life. Under the measures were taken by governments; education in countries was stopped temporary and art and design education were carried to the computer environment. This research aims to determine the students' opinions about the art and design education are made through distance education during the Covid-19 pandemic. A descriptive research method was used to determine the current situation. The data required for the research were collected with a data collection tool developed by the researcher. The obtained data were analysed using frequency (f) and percentage (\%) and the results of the research are revealed. As a result of the research, it has been found that following art and design education with a distance education model was not convenient for the majority of students. In addition to this result, it has also been found that 224 of 326 students felt that they could not achieve the aims of practical courses in the distance education model. From all these mentioned results, it may be recommended that additional measures should be taken to transfer the aim of practical courses to students in distance education.
\end{abstract}

Keywords: art education, distance education, coronavirus (covid-19), practical courses

\section{Introduction}

\subsection{Introduce the Problem}

The coronavirus (Covid-19) pandemic spread to the entire world at the beginning of 2020 and affected all areas of social life. "On 30th January 2020, the WHO Emergency Committee declared a global health emergency based on growing case notification rates at Chinese and international locations" (Velavan \& Meyer, 2020). After this declaration, various measures were taken by governments in all countries to protect their citizens: borders were closed, flights were stopped, and the governments have been called citizens to stay at home. The measures and the rules of social and physical distancing caused individuals to be distant from each other. As in all social life, the art and design process in countries was affected by this pandemic. Under the measures were taken by governments; museums closed and have been visited virtually, concerts were cancelled and watched on television or through social media channels such as youtube, Instagram, etc., artistic meetings were held with video conferences and many practices of culture, art, and design were carried to the computer environment. In addition to artistic activities, education in countries was closed temporarily. "Many institutions have opted to cancel all face-to-face classes, including labs and other learning experiences, and have mandated that faculty move their courses online to help prevent the spread of the virus that causes COVID-19" (Hodges et al., 2020). Indeed, numerous countries around the world decided to close schools nationwide to prevent or contain the spread of the virus, significantly affecting the learning of millions of children and adolescents (Ferri et al., 2020). UNESCO (2020) stated that temporary closure of schools to prevent the spread of the virus in the Covid-19 pandemic affected 1.72 billion students worldwide and 24.9 million students in Turkey. Until the beginning of the Covid-19 pandemic, distance education, which progressed in line with the future visions and the technical infrastructures of schools, has taken on different dimensions with the pandemic and has become compulsory for all countries. Different countries worldwide have introduced various solutions during the pandemic to continue the education process. "Online libraries, TV broadcasts, guidelines, resources, video lectures, online channels were introduced in at least 96 countries" (Basilaia \& Kvavadze, 2020). "Distance learning depending on the technological infrastructure and opportunities of the countries; are tried to be realized by using one or more of the tools such as printed teaching 
materials, radio broadcasts, television broadcasts, online teaching content or online interactive live lessons" (Karip, 2020).

The distance education method, which can be applied in all sub-disciplines of educational sciences (mathematics, physics, history, etc.) is also applied in art and design practices. It is seen that the technological developments that have led people and organizations to change have been shaped around the computer and then the internet, which has affected all areas of human and social life in the last century. "In this context, it is observed that the internet is the basic element shaping art and education in the information age" (Unalan, 2016). "New technologies hold incredible potential for the art education community. The Internet can provide not only a new form of communication but new forms of visuality" (Sweeny, 2004). "The technology is available, and the techniques are effective for undergraduate and graduate students to have success in online studio art courses" (Sheldon, 2009).

Various technologies, whose activities are increasing at the beginning of the 21 st century and combined with today's education systems, offer more accessible opportunities for anyone who wants to learn. Thanks to these opportunities, individuals can continue their learning processes outside the school boundaries. In addition to traditional mass media such as newspapers, television, and radio, many platforms shaped based on computer technologies are used as learning environments. "Over the years, various new technologies have been tried and tested for their potential use in education, particularly to expand access - including broadcast radio and television, audio, and video cassettes, teleconferencing and videoconferencing, computer conferencing and computer-assisted instruction" (D'Antoni \& Savage, 2009). It has been understood that many methods tried in this process can be used effectively in the teaching and learning process and knowledge can be transferred. One of the methods revealed differently from the conventional education systems realized in school classes is the 'distance education' method. "Distance education is teaching and planned learning in which teaching normally occurs in a different place from learning, requiring communication through technologies as well as a special institutional organization" (Moore \& Kearsley, 2012).

When taken within the conceptual framework it can be seen that the concept of distance education has a history of 120 years. "The term of distance education first appears in the catalogue of Wisconsin University in 1892" (Verduin \& Clark, 1994). It is stated that similar studies were carried out in the national educational literature 35 years after its first use in the international literature. "The first distance education studies in Turkey have entered the agenda with "teacher training report" presented by Dewey in 1924, it began to form as a concept in 1927" (Alkan as cited in Sager, Eden, \& Salliel, 2014). In the process in which international developments are followed and transferred to the national education system; the first implementation of the distance education model started in 1958, and in 1974, the letter teaching model was implemented within the Ministry of National Education (MEB, 2020). "With the law numbered 2547 published in 1981, the duty of performing open education activities was given to universities and with the decision in 1982, Anadolu University was assigned to perform open education activities. In subsequent years, with contributions from Firat University, Middle East Technical University, and Sakarya University distance education applications have become widespread in Turkey" (Gurer, Tekinarslan \& Yavuzalp, 2016). "By 1992, Film Radio and Television Education Centre, whose foundation dates to the 1950s, was granted the department status affiliated to the Ministry of National Education. Under this department, an open education high school was established which aims to enable individuals outside the formal education to receive high school education via the distance education method" (Basbug \& Basbug, 2016). "Example of the distance education model carried out at higher education level through Anadolu University has seen in 1996. The first Virtual Design Studio, used for art education, was established in 1997" (Broadfoot \& Bennett, 2003). "Bilkent University has attempted to conduct some courses from the USA by establishing the video conference system. Within the scope of distance education through the program called "New York on Air", some lessons were given by Professor Jonas Prager in Bilkent's New York office through the video conference system" (Bozkurt, 2017). This initiative is defined as the first real distance education application using the internet, which is the main source of today's information and communication technologies.

"Distance Education applications are divided into two as synchronous and asynchronous in terms of the teaching method and communication options" (Maher, Simoff, \& Cicognani, 2000). The main variable of the distinction is time. If the teacher and the learner perform the teaching process in the same timeframe, it is expressed as asynchronous or simultaneous course. Isik, Karaca, Ozkaraca, and Birogul (2010) defined synchronous education as a virtual classroom system in which students and teachers come together through various methods. The method in which the teacher stores the teaching process, which is based on the course objectives and content, through various platforms in a group in regular groups and that the student completes the learning process by accessing this platform independently from time, is expressed as an asynchronous or asynchronous course. "Asynchronous education is a distance learning method where participants can communicate via e-mail, message boards or online 
environments such as a forum, even if they are not in the same place and at the same time" (Hrastinski as cited in Akcay \& Gokcearslan, 2016).

There are many platforms to follow synchronous or asynchronous lessons. "Distance education platforms produced by various software companies are listed as Adobe Connect, Angel, Blackboard, Claroline, Elluminate Live!, Ideal, Moodle, Nefsis, Saba Centra Live and Web Ex" (Akcay \& Gokcearslan, 2016). The basic principle of these applications is that they create a 'virtual classroom' environment for students. In synchronous lessons, the teacher can share his/her video image, sound, own device screen, and any files (documents) with the students in the virtual classroom simultaneously and give feedback to the students' audio or video questions. But in the asynchronous courses; the students follow all the processes mentioned above through the images, sound, and documents previously recorded in the system.

\subsection{Aim of the Research}

In the related literature mentioned above; because of the closer relationship with information and communication technologies compared to other art branches, it is seen that there are many studies on distance education methods in Graphic Design. However, it should be stated that distance education has an appropriate process not only in the field of graphic design but also in all art branches. "Educational technologies are challenging the educational contexts of learning and initiating important issues about curriculum, pedagogy, intercultural communication, research, and administration in education and art education" (Krug, 2004). "Theoretical and practical (practical) courses in the field of art and design can be given through distance education through today's technical infrastructures. As in many countries, arts and design practices in Turkey can be given by distance learning" (Akcay \& Gokcearslan, 2016). By 2020, it is seen that distance education method has started to become widespread in different educational levels in the fields of art and design. Many of today's educational institutions support their theoretical and practical education and training activities with the distance education model and provide their art and design practices through distance education.

This research focused on the distance education process that emerged under the conditions of the Covid-19 pandemic. Education institutions providing education in the fields of art and design in the Covid-19 pandemic have also started to continue education with the distance education methods. The adoption of online learning in a situation of emergency represents a need, but it has also stimulated experts, policymakers, citizens, teachers, and learners to search for new solutions (Ferri et al., 2020). This situation reveals many problems in a short time and the situation that needs to be examined in detail. Also, the same process allowed the determination of the current situation arising during the 'compulsory' experience in art and design practices. The term compulsory is similar to the term 'emergency remote teaching (ERT)' mentioned by Hodges et al. (2020). "In contrast to experiences that are planned from the beginning and designed to be online, emergency remote teaching (ERT) is a temporary shift of instructional delivery to an alternate delivery mode due to crisis circumstances" (Hodges et al., 2020). In this sense, it should be noted that online learning is a different concept from emergency remote teaching.

The aim of this research is to determine the students' opinions about the art and design practices are made through distance education during the Covid-19 pandemic. Depending on the main aim of the research, the research questions are presented below:

What are the students' opinions about the current situation at distance education method?

What are the students' opinions about the aims, content, teaching and learning process, assessment and evaluation process of the practical art and design courses carried out by distance education method?

This research is one of the pioneering studies which examine the art and design practices in the times of Coronavirus (Covid-19) pandemic in Turkey. Furthermore, the research is considered important in terms of revealing the relationship between art and design practices and distance education methods. In addition, thanks to the research, it is envisaged to create a resource for similar research to be conducted in the future.

\section{Method}

In this research, descriptive research method was used to determine the students' opinions. "A descriptive research model aims to describe a situation that existed in the past or already exists in the present" (Kincal, 2010). "Descriptive research involves identification of attributes of a particular phenomenon based on an observational basis, or the exploration of the correlation between two or more phenomena" (Williams, 2007).

\subsection{Participants}

Students studying in different universities in the 2020-2021 academic year in Turkey have been identified as participants. The study group of the research consists of 326 students studying at art and design departments at 
universities in Turkey. The information of the study group by departments was presented in Table 1 .

Table 1. Information of the study group

\begin{tabular}{lccccccc}
\hline & \multicolumn{9}{c}{ Grades } & \multicolumn{2}{c}{ Total } \\
\hline Name of department & $1^{\text {st }}$ Grade & $2^{\text {nd }}$ Grade & $3^{\text {rd }}$ Grade & $4^{\text {th }}$ Grade & $9^{\text {th }}$ Semester and later* & f & $\%$ \\
\hline Painting & 10 & 26 & 28 & 26 & 8 & 98 & $30.06 \%$ \\
Industrial Products Design & 46 & 40 & 58 & 44 & 12 & 200 & $61.35 \%$ \\
Graphic Design & 14 & 14 & 0 & 0 & 0 & 28 & $8.59 \%$ \\
TOTAL & 70 & 80 & 86 & 70 & 20 & 326 & $100 \%$ \\
\hline
\end{tabular}

* There are 8 semesters (four grades) in Turkish Higher Education system. But some students cannot be able to graduate in 8 semesters and continue to educate in 9 th and later semesters.

\subsection{Data Collection}

Required data for the research were collected with a data collection tool developed by the researcher. The data collection tool that aims to determine the opinions related to the aim of the research; consists of 9 multiple choice questions and 14 items with a "typical five-level Likert type" scale. Inferences from the literature and the opinions of the field experts were used to determine the data collection tool items. In this context, literature related to the research subject was reviewed and items were established in accordance with the findings and results of research from the literature. Lawshe content validity method was used to determine the validity of the items. The determining items for the data collection tool were presented to three experts' opinions in the content validity study and 8 items were removed from the data collection tool based on the feedback. Cronbach's Alpha coefficient of the data obtained with the scale applied in the pilot study was calculated as $\alpha=.891$. In addition, no item with a negative item-total correlation was detected. Alpha reliability value between 0.80 and 1.0 indicates that the survey is highly reliable (Buyukozturk, 2009). According to the content validity study and calculated Cronbach's Alpha coefficient, it can therefore be said that the data collection tool was valid and highly reliable. After the results of the reliability and validity studies, the electronic data collection tool was applied to the students on the dates between 5th and 25th January 2021.

\subsection{Data Analysis}

332 students participated in the data collection process. In the pre-examination of the data collection tools answered by students, it was determined that 6 of 332 students were missing or answered incorrectly and these forms were excluded from the analyse. The eligible quantitative data was analysed by using SPSS 15 for Windows and Microsoft Excel software. Frequency (f) and percentages (\%) were used to analyse the opinions of 326 students to the data collection tool. In addition, 38 of 326 students answered the open-ended question. All the answers given by students to the open-ended question numbered as S1 (Student1), S2, S3, etc. Qualitative data were analysed by the content analysis method. In this context the obtained data were added to the related themes. The answers were analysed by grouping them under various themes depending on the research questions and findings related to the sub-objectives of the research were revealed.

\section{Results}

In this title, the findings regarding the students' opinions about the art and design practices are taught through distance education during the Covid-19 pandemic are presented. The typical five-level Likert scale was preserved in the table contents presented in the findings, but in order to simplify the understanding of the findings; the answers were interpreted by grouping them as 'agree', 'undecided', and 'disagree'.

In order to find the answers to the first question of the research; four yes/no questions, two sufficiency questions, and one frequency question were asked to the students. The students' opinions about the current situation at distance education method are presented in Table 2. 
Table 2. Students' opinions about the current situation at distance education method

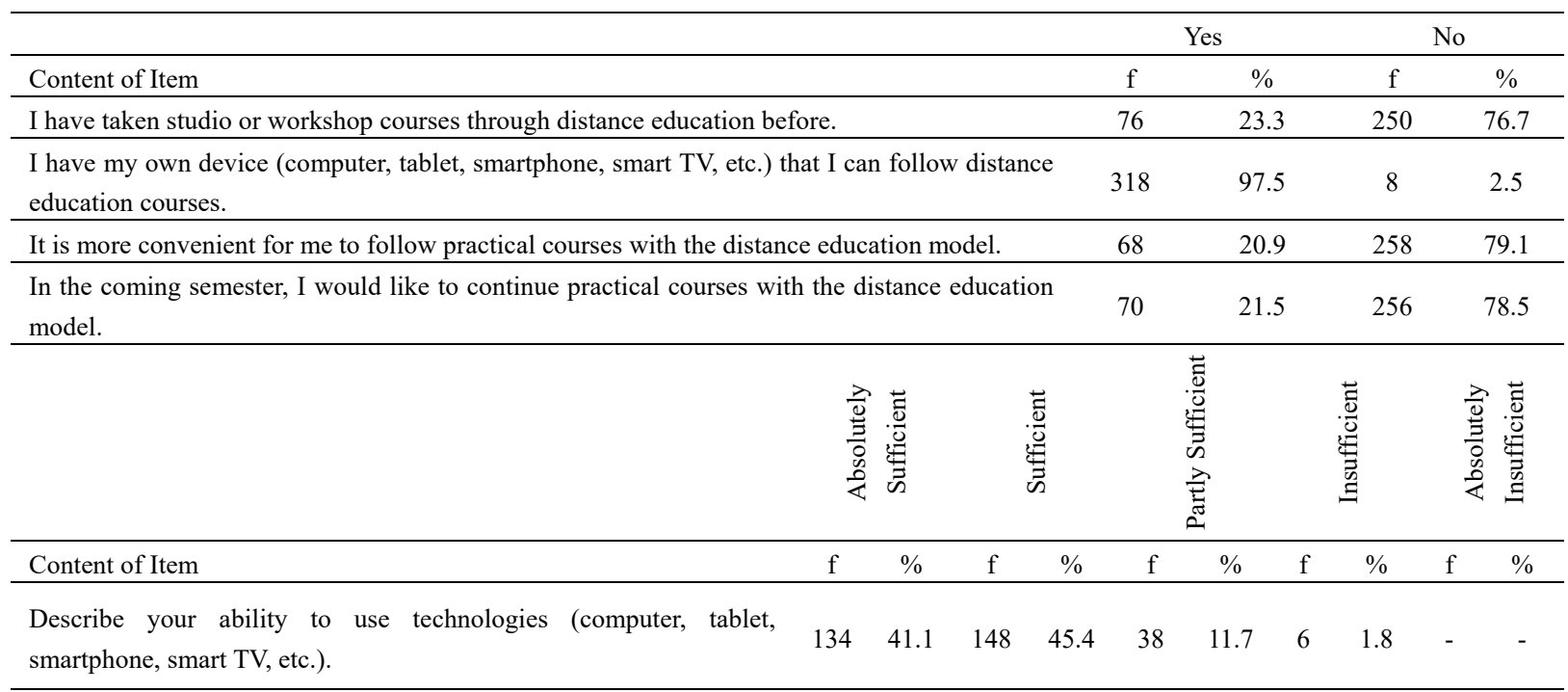

The technical infrastructure used by our university for the distance education model is sufficient.

$\begin{array}{llllllllll}16 & 4.9 & 104 & 31.9 & 138 & 42.3 & 54 & 16.6 & 14 & 4.3\end{array}$

\begin{tabular}{|c|c|c|c|c|c|c|c|c|c|c|}
\hline & \multicolumn{2}{|c|}{ 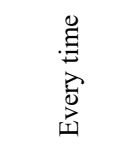 } & \multicolumn{2}{|c|}{ 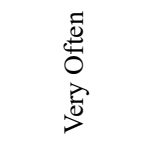 } & \multicolumn{2}{|c|}{ 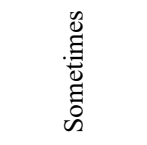 } & \multicolumn{2}{|c|}{$\frac{\lambda}{\stackrel{0}{\Xi}}$} & \multicolumn{2}{|c|}{ 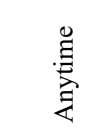 } \\
\hline Content of Item & $\mathrm{f}$ & $\%$ & $\mathrm{f}$ & $\%$ & $\mathrm{f}$ & $\%$ & $\mathrm{f}$ & $\%$ & $\mathrm{f}$ & $\%$ \\
\hline $\begin{array}{l}\text { I had problems with connection, video or audio in distance education } \\
\text { courses. }\end{array}$ & 42 & 12.9 & 110 & 33.7 & 144 & 44.2 & 22 & 6.7 & 8 & 2.5 \\
\hline
\end{tabular}

When the first and the second yes/no questions in Table 2 is examined, it is seen that $76.7 \%$ of students have not took studio or workshop courses through distance education before and $97.5 \%$ of students have own device (computer, tablet, smartphone, smart TV, etc.) that they can follow distance education courses. From these findings, it can be said that most of the students followed the art and design courses for the first time through distance education and most of the students followed the online courses from their own devices. When the third and the fourth yes/no questions in Table 2 is examined, it is seen that following art and design practices with distance education model was not convenient for $79.1 \%$ of students. When the open-ended question in the survey is analysed, it is seen that similar opinions are expressed there. S7 says: 'Distance education may be a convenient and appropriate choice for theoretical lessons, although it is not sufficient in practical courses.' and S25 says: 'If distance education is useful, why do we travel $1000 \mathrm{~km}$ for learning?' Depending on this finding, 78.5\% of students would not like to continue art and design practices with the distance education model in the coming semester. Same opinions can be seen in open-ended answers. S33 says: 'Everything was very good, but please courses do not online next semester.' and S46 says: 'Please delete the continuation of the distance education from your mind. There is no system that can replace formal education.' A small number of students put forward opposite opinions. S66 says: 'I want both theoretical and practical courses to continue with distance education in the next semester, as long as the pandemic continues.' $\mathrm{S} 161$ says: 'I think the distance education model is definitely more convenient than face to face education. ' When the first sufficiency questions in Table 2 is examined, it is seen that $41.1 \%$ of students selected 'Absolutely Sufficient', $45.4 \%$ selected 'Sufficient', $11.7 \%$ selected 'Partly Sufficient', $1.8 \%$ selected 'Insufficient', while there is any student selected 'Absolutely Insufficient'. From this finding, it can be said that most of the students have high ability to use technologies (computer, tablet, smartphone, smart TV, etc). When the last two questions in Table 2 is examined, it is seen that $4.9 \%$ of students selected 'Absolutely Sufficient', 31.9\% selected 'Sufficient', 42.3\% selected 'Partly Sufficient', 16.6\% selected 'Insufficient' and 4.3\% selected 'Absolutely Insufficient'. In open-ended answers S33 says: 'Yes, we had to process the lessons online. Our system was installed faster than most universities.' and S61 says: 'I believe that our university showed the expected devotion to distance education in the difficult period we are experiencing. 'But according to the students' opinions it is understood that $90.8 \%$ of students had problems (sometimes to every time) with connection, video, or 
audio in distance education courses. In open-ended answers S5 says: 'We could not connect to synchronous lessons due to problems on the internet, we had problems in exams. 'From this finding, it can be said that the students thought the technical infrastructure used by their university for the distance education model is sufficient.

In order to find the answers to the second question of the research, three question were asked to the students. The students' opinions about the aims of the art and design practices carried out by distance education method are presented in Table 3.

Table 3. Students' opinions about the aims of the practical art and design courses

\begin{tabular}{|c|c|c|c|c|c|c|c|c|c|c|}
\hline & & 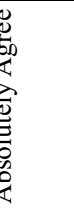 & & te & & 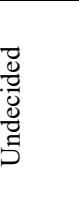 & & 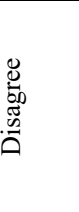 & 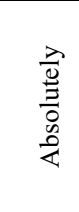 & 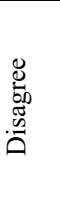 \\
\hline Content of Item & $\mathrm{f}$ & $\%$ & $\mathrm{f}$ & $\%$ & $\mathrm{f}$ & $\%$ & $\mathrm{f}$ & $\%$ & $\mathrm{f}$ & $\%$ \\
\hline $\begin{array}{l}\text { The distance education model was more useful (compared to } \\
\text { face-to-face education) to achieve the aims of practical course. }\end{array}$ & 20 & 6.1 & 18 & 5.5 & 56 & 17.2 & 88 & 27.0 & 144 & 44.2 \\
\hline $\begin{array}{l}\text { In the distance education model, I felt that I could not achieve the aims } \\
\text { of practical course. }\end{array}$ & 120 & 36.8 & 104 & 31.9 & 42 & 12.9 & 40 & 12.3 & 20 & 6.1 \\
\hline $\begin{array}{l}\text { The distance education model made me think that the aims of practical } \\
\text { course were insignificant. }\end{array}$ & 42 & 12.9 & 82 & 25.2 & 92 & 28.2 & 90 & 27.6 & 20 & 6.1 \\
\hline
\end{tabular}

When the first item of Table 3 is examined, it can be seen that $11.6 \%$ of students 'agree', $17.2 \%$ of students' 'undecided', and $71.2 \%$ of students 'disagree'. In open-ended answers, S10 says: 'It is obvious that practical courses are not efficient and understandable.' and S36 says: 'Distance education was not useful for me in any way, we take a lesson that is difficult to understand even when faced.' From this finding, it can be said that students do not believe that the distance education model was more useful (compared to face-to-face education) to achieve the aims of the practical course. When the second item of Table 3 is examined, it is seen that $68.7 \%$ of students 'agree', $12.9 \%$ of students' 'undecided' and $18.4 \%$ of students 'disagree'. In open-ended answers, S39 says: 'I do not think that distance education was efficient for practical courses.' and S47 says: 'Painting cannot be taught by distance education.' According to this finding, it can be said that most of the students felt that they could not achieve the aims of practical course in distance education model. When the third item of Table 3 is examined, it is seen that $38.1 \%$ of students 'agree', $28.2 \%$ of students' 'undecided' and $33.7 \%$ of students 'disagree'. 'Neither Agree nor Disagree' selection seems to be most in Table 3 but when grouping agree and disagree selections, agreed students are more than undecideds. According to this finding, it can be said that most of the students agree that the distance education model made students thought that the aims of practical courses were insignificant.

In order to find the answers to the third question of the research, four question were asked to the students. The students' opinions about the content of the art and design practices carried out by distance education method are presented in Table 4. 
Table 4. Students' opinions about the content of the practical art and design courses

\begin{tabular}{lllllll}
\hline & & & \\
& & & & & \\
\hline
\end{tabular}

When the first item of Table 4 is examined, it is seen that $14.8 \%$ of students 'agree', $12.3 \%$ of students' 'undecided' and $73 \%$ of students 'disagree'. In open-ended answers, S70 says: 'I would like to declare and state that the practical course taught via distance education is not suitable for our department and its content did not add anything to us.' According to this finding, it can be said that the students could not understand the course contents better when they took the practical courses through distance education. When the second item of Table 4 is examined, it is seen that $47.9 \%$ of students 'agree', $19.6 \%$ of students' 'undecided' and $32.5 \%$ of students 'disagree'. According to this finding, it can be said that students think that duration of synchronous (live) course are adequate to learn the course content. When the third item of Table 4 is examined, it is seen that $21.4 \%$ of students 'agree', $18.4 \%$ of students' 'undecided' and $60.1 \%$ of students 'disagree'. In open-ended answers, S148 says: 'I think the factors that negatively affect distance education are caused by pandemics. In a period when there is no pandemic, I believe that distance education will be very productive and will affect motivation positively.' From this finding, it can be said that the distance education model negatively affected students learning motivation. When the fourth item of Table 4 is examined, it is seen that $42.9 \%$ of students 'agree', $17.8 \%$ of students' 'undecided' and $39.3 \%$ of students 'disagree'. According to this finding, it can be said that the adequate methods or materials were used to transfer the content of practical courses.

In order to find the answers to the fourth question of the research, four questions were asked to the students. The students' opinions about the teaching and learning process of the art and design practices carried out by distance education method are presented in Table 5.

Table 5. Students' opinions about the teaching and learning process of the practical art and design courses

\begin{tabular}{|c|c|c|c|c|c|c|c|c|c|c|}
\hline & & $\frac{\pi}{4}$ & & 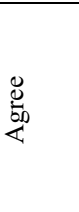 & & 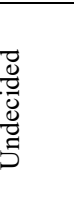 & & D. & 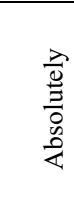 & 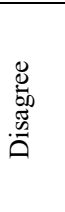 \\
\hline Content of Item & $\mathrm{f}$ & $\%$ & $\mathrm{f}$ & $\%$ & $\mathrm{f}$ & $\%$ & $\mathrm{f}$ & $\%$ & $\mathrm{f}$ & $\%$ \\
\hline $\begin{array}{l}\text { The virtual classroom application reflected the workshop/studio } \\
\text { communication exactly in the teaching and learning process. }\end{array}$ & 12 & 3.7 & 54 & 16.6 & 52 & 16.0 & 102 & 31.3 & 106 & 32.5 \\
\hline $\begin{array}{l}\text { While in the synchronous lesson, I felt myself in the studio or workshop } \\
\text { environment. }\end{array}$ & 14 & 4.3 & 28 & 8.6 & 18 & 5.5 & 98 & 30.1 & 168 & 51.5 \\
\hline $\begin{array}{l}\text { Conducting practical courses through distance education model made it } \\
\text { easier for me to learn. }\end{array}$ & 18 & 5.5 & 32 & 9.8 & 40 & 12.3 & 116 & 35.6 & 120 & 36.8 \\
\hline $\begin{array}{l}\text { Lectures used the technical infrastructure without any problems during } \\
\text { the teaching and learning process. }\end{array}$ & 20 & 6.1 & 96 & 29.4 & 80 & 24.5 & 98 & 30.1 & 32 & 9.8 \\
\hline
\end{tabular}

When the first item of Table 5 is examined, it is seen that $20.3 \%$ of students 'agree', $16 \%$ of students' 'undecided' 
and $63.8 \%$ of students 'disagree'. In open-ended answers, S60 says: 'Face to face education is really important socially.' and S128 says: 'The virtual classroom and the real workshop environment cannot be placed on the same scale. Practical courses are more successful with face-to-face education. 'From this finding, it can be said that the virtual classroom application did not reflect the workshop/studio communication exactly in the teaching and learning process. When the second item of Table 5 is examined, it is seen that $12.9 \%$ of students 'agree', $5.5 \%$ of students' 'undecided' and $81.6 \%$ of students 'disagree'. In open-ended answers, S132 says: 'Practical courses should proceed in a way that we can exchange ideas with our friends.' According to this finding, it can be said that most of the students did not feel themselves in the studio or workshop environment while in the synchronous lesson. When the third item of Table 5 is examined, it is seen that $15.3 \%$ of students 'agree', $12.3 \%$ of students' 'undecided' and $72.4 \%$ of students 'disagree'. In open-ended answers, S70 says: 'I would like to state that the studio course, in which we are in mutual communication, and we are constantly active, is not carried out efficiently.' From this finding, it can be said that conducting practical courses through distance education model did not make it easier for students to learn. When the fourth item of Table 5 is examined, it is seen that $35.5 \%$ of students 'agree', $24.5 \%$ of students' 'undecided' and $39.9 \%$ of students 'disagree'. From this finding, it can be understood that many lectures had problems with technical infrastructure in teaching and learning process.

In order to find the answers to the fifth question of the research, three questions were asked to the students. The students' opinions about the assessment and evaluation process of the art and design practices carried out by distance education method are presented in Table 6.

Table 6. Students' opinions about the assessment and evaluation process of the practical art and design courses

\begin{tabular}{|c|c|c|c|c|c|c|c|c|c|c|}
\hline & & 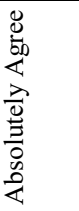 & & 退 & & 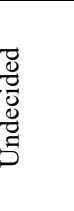 & & 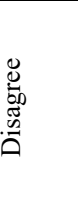 & 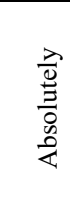 & 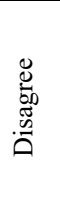 \\
\hline Content of Item & $\mathrm{f}$ & $\%$ & $\mathrm{f}$ & $\%$ & $\mathrm{f}$ & $\%$ & $\mathrm{f}$ & $\%$ & $\mathrm{f}$ & $\%$ \\
\hline $\begin{array}{l}\text { The appropriate method (application, project, homework, research, etc.) } \\
\text { was chosen to conduct the assessment and evaluation process of the } \\
\text { practical course according to the distance education model. }\end{array}$ & 34 & 10.4 & 176 & 54.0 & 62 & 19.0 & 42 & 12.9 & 12 & 3.7 \\
\hline $\begin{array}{l}\text { The assessment and evaluation process in practical courses were fairly } \\
\text { and transparently. }\end{array}$ & 30 & 9.2 & 106 & 32.5 & 72 & 22.1 & 54 & 16.6 & 64 & 19.6 \\
\hline $\begin{array}{l}\text { The teacher gave sufficient feedback to the practical studies I submitted } \\
\text { in the exam. }\end{array}$ & 52 & 16.0 & 130 & 39.9 & 56 & 17.2 & 48 & 14.7 & 40 & 12.3 \\
\hline
\end{tabular}

When the first item of Table 6 is examined, it is seen that $64.4 \%$ of students 'agree', $19 \%$ of students' 'undecided' and $16.6 \%$ of students 'disagree'. In open-ended answers, S27 says: 'I had a problem when I tried to send the exams of practical courses via e-mail. While I normally do the exam and get a high score, I hardly passed a course because I had trouble with e-mail.' S64 says: 'The problem of living in quarantine especially in the big city caused us to return to homework given from each course in the most inefficient and fastest way.' and S87 says: 'Unfortunately, since most tools and equipment were not sold nearby, we had to give the finals by hand drawing'. According to this finding, it can be understood that appropriate method was chosen to conduct the assessment and evaluation exam of the practical course according to the distance education model. When the second item of Table 6 is examined, it is seen that $41.7 \%$ of students 'agree', $22.1 \%$ of students' 'undecided' and $36.2 \%$ of students 'disagree'. In open-ended answers, S149 says: 'The assessment and evaluation process in practical courses were never fair.' According to this finding, it can be understood that assessment and evaluation process in practical courses were fairly and transparently. When the third item of Table 6 is examined, it is seen that $55.9 \%$ of students 'agree', $17.2 \%$ of students' 'undecided' and $27 \%$ of students 'disagree'. From this finding, it can be said that the student took sufficient feedback to the practical studies they submitted in the exam.

\section{Discussion}

The results of the research aiming to determine students' opinions regarding the practical art and design courses are made through distance education during the Covid-19 pandemic are presented below. As a result of the current situation at distance education method, it has been found that three-quarters of the students have not taken studio or workshop courses through distance education before, and they followed the art and design courses for the first time through distance education in this semester. Almost all students (except for 8 students) have their own device and 
they can follow distance education courses from their own devices. In addition to these results, it has also been found that following art and design practices with distance education model was not convenient for the majority of students and they would not like to continue art and design practices with the distance education model in the coming semester. A similar result can be seen in another research in the field of music. In the research conducted by Sager, Eden, and Salliel (2014), the rate of those who think that it will be correct to give practical (performance) courses through distance education are $27 \%$.

The answers to two sufficiency questions in order to find the answers to the current situation at distance education method, it has been concluded that both students' ability and technical infrastructure of the university is sufficient to follow distance education model. However, despite these two results, it was understood that the students still had problems with connection, video, or audio in distance education courses. From all these mentioned results, it may be recommended that the distance education method in this field should not be maintained without making the most suitable planning for the specialty of the art and design practices. According to Krug (2004), it is time to analyse critically our own positions, practices, and policies concerning the effective use of technology in learning.

As a result of the aims of the art and design practices, it has been found that only 38 of 326 students stated that the distance education model was more useful than face-to-face education. On the other hand, 232 of 326 the student (three-quarters) state the opposite. Related to aims, it has been found that 224 of 326 students felt that they could not achieve the aims of practical courses in the distance education model. At the same time, this result also led to students perceives the aims as insignificant. From all these mentioned results, it may be recommended that face-to-face education should be preferred for practical courses, but in compulsory situations, additional measures should be taken to transfer the aim of practical courses to students.

As a result of the content of the art and design practices, it has been found that the students could not understand the course contents better when they took the practical courses through distance education. It has also been found that the distance education model negatively affected students learning motivation. In the research in which Kalelioglu, Atan, and Cetin (2016) examined the teachers' and students' experiences in the virtual classroom environment, it was observed that the students had problems with communication and distraction. There are positive opinions about the content of the art and design practices. According to students' opinions, it was understood that the duration of the synchronous (live) course is adequate to learn the course content and methods or materials used in transferring the content of practical courses are adequate.

As a result of the teaching and learning process of the art and design practices, it has been found that there are many problems with the teaching and learning process of the art and design practices. Four items were presented to students and the students stated negative opinions for all the items regarding the teaching and learning process. According to findings, it can be said that the virtual classroom application did not reflect the workshop/studio communication exactly in the teaching and learning process and most of the students did not feel themselves in the studio or workshop environment while in the synchronous lesson. It was also found that conducting practical courses through the distance education model did not make it easier for students to learn. "Thus, careful planning for online learning includes not just identifying the content to cover but also carefully tending to how you are going to support different types of interactions that are important to the learning process. This approach recognizes learning as both a social and a cognitive process, not merely a matter of information transmission" (Hodges et al., 2020). In addition to these results, it can be stated that many lectures had problems with technical infrastructure in the teaching and learning process. From all these mentioned results about the content and the teaching and learning process, various suggestions can be made. Firstly, it can be stated that the communication of students in the classroom is at the forefront in practical courses. And this communication is also the source of motivation. The students in practical courses wander in the workshop or studio to examine the work of other students and find answers to various questions by talking to them. For this reason, to increase student motivation, it may be suggested to allow students to communicate with each other during the online course and to prefer distance education methods that enable communication in the classroom. Providing these opportunities enables students to understand the content more easily and have high motivation.

As a result of the assessment and evaluation process of the art and design practices; apart from a few opposite opinions, it was understood that most students stated positive opinions about the assessment and evaluation process of the art and design practices. According to findings, it has been found that the chosen method to conduct the assessment and evaluation exam of the practical course according to the distance education model is appropriate. It has also been found that the assessment and evaluation process in practical courses were fairly and transparent and the lectures gave sufficient feedback to the practical studies. In addition to these results, it should be stated that the process and individual development in art education are at least as important as the result. For this reason, it should be suggested that the distance education method should not only focus on the result and observe 
the process and development of students in the artistic production.

\section{References}

Akcay, S., \& Gokcearslan, A. (2016). Perceptions of students and an application about the use of distance education method in graphic design course: Gazi University case. Kastamonu Education Journal, 24(4), 1983-2004.

Basbug, F., \& Basbug, Z. (2016). Notes on visual arts education. The Journal of Akdeniz Sanat, 9(18), 74-98.

Basilaia, G., \& Kvavadze, D. (2020). Transition to online education in schools during a sars-cov-2 coronavirus (covid-19) pandemic in Georgia. Pedagogical Research, 5(4). https://doi.org/10.29333/pr/7937

Bozkurt, A. (2017). The past, present and future of the distance education in Turkey. AUAd, 3(2), 85-124.

Broadfoot, O., \& Bennett, R. (2003). Design Studios: Online? Comparing Traditional Face-to-face Design Studio Education with Modern Internet-based Design Studios. Apple University Consortium Academic and Developers Conference Proceedings, Sydney.

Buyukozturk, S. (2009). Sosyal bilimler icin veri analizi el kitabi. Ankara: Pegem A Yayincilik. https://doi.org/10.14527/9789756802748

D’Antoni, S., \& Savage, C. (2009). Open Education resources: Conversations in cyberspace. UNESCO Publishing. Retrieved form https://unesdoc.unesco.org/ark:/48223/pf0000181682

Ferri, F., Grifoni, P., \& Guzzo, T. (2020). Online learning and emergency remote teaching: opportunities and challenges in emergency situations. Societies, 10(4), 86-104. https://doi.org/10.3390/soc10040086

Gurer, M. D., Tekinarslan, E., \& Yavuzalp, D. (2016). Opinions of instructors who give lectures online about distance education. Turkish Online Journal of Qualitative Inquiry, 7(1), 47-78. https://doi.org/10.17569/tojqi.74876

Hodges, C., Moore, S., Lockee, B., Trust, T., \& Bond, A. (2020). The difference between emergency remote teaching and online learning. EDUCAUSE Review. Retrieved from https://er.educause.edu/articles/2020/3/ the-difference-between-emergency-remote-teaching-and-online-learning

Isık, A. H., Karaca, A., Ozkaraca, O., \& Birogul, S. (2010). Comparative Analysis of Web Based Concurrent (Synchronous) Distance Education Systems. Akademik Bilisim'10 Conference Proceedings, Mugla University.

Kalelioglu, F., Atan, A., \& Cetin, C. (2016). Experiences of instructors and learners in a virtual classroom environment. Mersin University Journal of the Faculty of Education, 12(2), 555-568. https://doi.org/10.17860/efd.34388

Karip, E. (2020). COVID-19: school closures and beyond. Retrieved from https://tedmem.org/vurus/covid-19okullarin-kapatilmasi-ve-sonrasi

Kincal, R. Y. (2010). Scientific research methods [Bilimsel arastirma yontemleri]. Ankara: Nobel.

Krug, D. H. (2004). Leadership and research: Reimagining electronic technologies for supporting learning through the visual arts. Studies in Art Education, 46(1), 3-5. https://doi.org/10.1080/00393541.2004.11650064

Maher, M. L., Simoff, S. J., \& Cicognani, A. (2000). Understanding virtual design studios. London: Springer-Verlag. https://doi.org/10.1007/978-1-4471-0729-3

MEB [Turkish Ministry of National Education]. (2020). History of open high school. Retrieved from https://aol.meb.gov.tr/www/okulumuz/icerik/1

Moore, M., \& Kearsley, G. (2012). Distance education: A systems view of online learning (3rd ed.). Belmont, CA: Wadsworth Cengage Learning.

Sager, T., Eden, A., \& Salliel, O. (2014). Distance learning in music education and orchestral applications. Inonu University Journal of Art and Design, 4(9), 69-79.

Sheldon, K. E. (2009). International trends and techniques used to teach studio art courses through distance education (Unpublished dissertation). United States of America: East Carolina University.

Sweeny, R. W. (2004). Lines of sight in the "network society": Stimulation, art education, and a digital visual culture. Studies in Art Education, 46(1), 74-87. https://doi.org/10.1080/00393541.2004.11650070

Unalan, H. T. (2016). Creating internet-based learning environments in the departments of education faculty fine 
arts education. AUAd, 2(1), pp.130-147.

UNESCO (2020). COVID-19 Educational Disruption and Response. Retrieved from https://en.unesco.org/covid19/educationresponse

Velavan, T. P., \& Meyer, C.G. (2020). The COVID-19 epidemic. Tropical Medicine and International Health, 25(3), 278-280. https://doi.org/10.1111/tmi.13383

Verduin, J. R., \& Clark, Jr. T. A. (1994). Uzaktan egitim: Etkin uygulama esaslari (Trans. Ilknur Mavis), Eskisehir: Anadolu University

Williams, C. (2007). Research methods. Journal of Business \& Economic Research, 5(3), 65-72.

\section{Copyrights}

Copyright for this article is retained by the author(s), with first publication rights granted to the journal.

This is an open-access article distributed under the terms and conditions of the Creative Commons Attribution license (http://creativecommons.org/licenses/by/4.0/). 